\title{
CHALLENGES IN CROSS CULTURAL ADVERTISING
}

\author{
Yuni Retnowati*
}

\begin{abstract}
ABSTRAK
Pada awalnya, para akademisi dan praktisi pemasaran menggunakan pendekatan yang terstandardisasi dalam strategi pemasaran dan periklanannya dalam era globalisasi. Namun, sejumlah penelitian menunjukkan bahwa standardisasi iklan lintas budaya tidak dapat dilakukan. Oleh karena itu, iklan lintas budaya kemudian menggunakan pendekatan budaya lokal dalam menyampaikan pesannya. Pemahaman lintas budaya sangat penting untuk menentukan keberhasilan iklan lokal, yaitu iklan yang mencerminkan nilai-nilai budaya dan norma khalayak sasaran. Adapun tantangan iklan lintas budaya terletak pada caranya dalam berkomunikasi dengan orang dari latar belakang budaya yang berbeda. Sementara itu, solusi iklan lintas budaya terletak pada penggunaan bahasa, gaya komunikasi, nilai budaya, dan pencitraannya. Secara sederhana, iklan lintas budaya adalah tentang penggunaan common sense dan analisis unsur-unsur kampanye periklanan yang dipengaruhi oleh budaya yang kemudian memodifikasinya agar bisa berkomunikasi dengan cara yang tepat kepada khalayak sasaran. Di samping itu, tantangan lainnya adalah menentukan antara standardisasi dan adaptasi kandungan nilai-nilai budaya dari iklan ketika menghadapi orang dari budaya yang berbeda. Di sisi akademis, tantangannya adalah mempersiapkan mahasiswa untuk merancang iklan yang mampu berkomunikasi secara efektif kepada khalayak sasaran dalam budaya yang beragam
\end{abstract}

Kata Kunci: globalisasi, nilai budaya, lintas budaya, periklanan, tantangan

\begin{abstract}
At first, marketing practitioners and academics consider standardized approaches to marketing and advertising strategies in globalization, and then some studies proved that the standardization of advertising across culture is not valid. Therefore, cross cultural advertising takes local culture into account when conveying messages in advertisements. Cross cultural understanding is very important in order to produce successful localized advertising that would reflect the cultural values and norms of intended audience. Challenge in cross cultural advertising is the problem of communicating to people of diverse cultural background. Cross cultural solutions are applied in areas such as language, communication style, images and cultural values. Cross cultural advertising is simply about using common sense and analyzing how the different elements of an advertising campaign are impacted by culture and modifying them to best speak to the target audience. Other challenges are determining between standardization and adaptation of cultural values content of advertising when facing different people from diverse cultures. In academic side, the challenge is preparing students to design advertisements that communicate effectively to diverse cultures.
\end{abstract}

Keywords: advertising, challenge, cross cultural, cultural value, globalization

\footnotetext{
* Indonesian Communication Academy, Yogyakarta
} 


\section{INTRODUCTION}

Globalization has increased dramatically in the early 21 st century. It is an era of global business and economic integration, the extent to which economic activity crosses national boundaries. Commercial products and services of giant multinationals have been marketed to people from different culture environments. In an increasingly global economic environment, international trade has achieved phenomenal growth resulting in increased international advertising across diverse cultures.

In 1983 Levitt affirmed that advertising and marketing can be standardized across cultures, and since then there has been a heated debate as to whether or not advertising can be standardized across cultures. In Levitt's view, globalization is transforming the world into a 'homo cultural' marketplace where all customers can be persuaded by the same advertising appeals and values, irrespective of the culture they belong to. However, there is an increasing body of research which casts serious doubts over the claims made by Levitt and which suggests that advertising is strongly influenced by local culture (Dahl, 2004).

The essence of advertising is convincing people that a product is meant for them. By purchasing it, they will receive some benefits, whether it be lifestyle, status, convenience or financial. However, when an advertising campaign is taken abroad, different values and perceptions as to what enhances status or gives convenience exist. These differences make the original advertising campaign defunct. Therefore cross cultural advertising campaign need an understanding of a particular culture and the creative execution must still take account of cultural differences.

An effective advertising must derive from and be part of a culture, sharing the language and values of the target audience. It is not simply a matter of choosing between a sparkling international creative strategy and execution which neglects local needs, motives, and buying habit, or a local campaign which strongly relates to local buying motives but inferior in terms of professionalism. The best aspect of the two approaches must be combined in order to produce an effective cross cultural advertising which can be easily adapted to local circumstances.
Cross cultural understanding is very important in order to be able to devise successful localized advertising that would reflect the cultural values and norms of its targeted audience. By understanding cross cultural differences or similarities in advertising strategy, expressions and manifest values and norms, we understand which aspects of advertising can be shared across several countries and conversely which aspect need to be adapted to local cultures.

In most cases, consumer's attitudes, awareness and behavior are largely driven by the framework of their own culture, which is not only communicated to people but also forms and modifies the communication among the people of a society. As Mooij (2010 : 46) points out, global marketing strategies is not culture free. Conversely, such strategies should be culture relevant because influences of culture on consumer behavior and perception of global marketing communications are powerful and profound. One of the greatest challenges in cross cultural advertising is the problem of communicating to people of diverse cultural background.

\section{GLOBALIZATION AND ADVERTISING}

Globalization is not a single process, but a set of processes that operate simultaneously and unevenly on several levels and in various dimensions. Among aforesaid dimensions one could find economic, political, cultural, ideological and ecological ways of manifestation of globalization and what is more important - the huge net of interdependencies between all these spheres (Steger, 2009: 36-37). Paul Hopper claims that globalization should be viewed as a multicentered phenomenon contributed to by a range of sources, powers and influences (Hopper, 2007:5).

Pieterse conceives globalization as human integration and hybridization, arguing that it is possible to detect forms of such cultural mixing across the world dating back many centuries (Hopper, 2007: 31).

Eriksen names three similar dimensions of contemporary globalization: "increased trade and transnational economic activity, faster and denser communication networks, increased tensions between cultural groups due to intensified mutual exposure." And he also stresses the idea that all 
these developments are not recent, but have roots in previous historical processes. Eriksen states that there is only one really new tendency in this period: globalization becomes the form of consciousness, and a global discourse and awareness about the world as a whole emerge (Eriksen, 2007: 4-5).

The same idea we can find in Roland Robertson's definition of globalization: "globalization as a concept refers to the intensification of consciousness of the world as a whole" (Robertson, 2009: 13). But also there are scholars, who favor the idea of contemporary period as unprecedented "qualitative leap", and globalization as something cardinally new and never before experienced. For example, Manuel Castells analyzes globalization through the idea of "the rise of Network Society", emphasizing the unparalleled nature of new Information and Communication Technology and the impact of integration the world into global communication networks (Hemer, Tufte 2005: 14).

Manfred (2009:10) argues that globalization has four main dimensions: economic, political, cultural, ecological, with ideological aspects of each category.

(1) Economic Globalization

Economic globalization is the intensification and stretching of economic interrelations around the globe. It encompasses such things as the emergence of a new global economic order, the internationalization of trade and finance, the changing power of transnational corporations, and the enhanced role of international economic institutions.

(2) Political Globalization

Political globalization is the intensification and expansion of political interrelations around the globe (Manfred, 2009 :11) Aspects of political globalization include the modern-nation state system and its changing place in today's world, the role of global governance, and the direction of our global political systems.

(3) Cultural Globalization

Cultural globalization is the intensification and expansion of cultural flows across the globe. Culture is a very broad concept and has many facets, but in the discussion on globalization, means it to refer to "the symbolic construction, articulation, and dissemination of meaning."
Topics under this heading include discussion about the development of a global culture, or lack thereof, the role of the media in shaping our identities and desires, and the globalization of languages.

(4) Ecological Globalization

Topics of ecological globalization include population growth, access to food, worldwide reduction in biodiversity, the gap between rich and poor as well as between the global North and global South, human-induced climate change, and global environmental degradation

Globalization in business significantly affects a company's advertising strategy and the way it delivers messages to customers. Developing and implementing an advertising strategy is a massive undertaking for global companies. A major strategic dilemma is whether to use a global, universal messaging approach or to customize advertising to each individual market. More companies use a multi-domestic or international approach since few products have truly universal use and message context.

One reason for increased strategic requirements with globalization is the impact of language and culture. Cultural familiarity is also an issue. To persuade people with advertising, advertiser must understand the culture and values. According to Neuliep (2003: 18) culture is an accumulated pattern of values, beliefs and behaviors shared by an identifiable group of people with a common history and a verbal and non verbal symbol system. We can not understand advertising unless we consider its cultural context. Culture is the lens through which consumers make sense of marketing communication. Each culture reflects, in its language and communication, what is of value to people.

Advertising attempts to sell goods by appealing to consumers through gender identity, celebrity endorsement, romantic imagery, notions of achieving happiness or contentment and other cultural dimension not tangibly related to the advertised product or service ( Jhally in Malefyt \& Moeran, 2003: 75).

The cultural dimension of advertising came age in 1920s. Agencies and publicists no longer sought merely to convey objective facts about the products they sought to link products with 
a particular lifestyle, imbue them with glamour and prestige to persuade potential consumers that purchasing an item could be described as a "personally fulfilling and enriching experience" (Brinkley, 2002). The images of ads sought to both resonate with and help define the lifestyles of those who bought the products.

Advertising is part of the glue that holds our culture together which allows us to share a common experience in a landscape populated by brands, images, logos and even jingles. It reflects and influences our cultural value and therefore it cannot be ignored when building effective advertising. Results show that culture impact execution more than creative strategy (Wei \& Jiang, 2005) and, therefore, execution is seen as an important element of cross cultural advertising

The standardized approach of advertising the product as "one sight one sound one sell" offers efficiencies in creation and production. In practice, the standardization perspective has not worked out too well. One reason for the failure of global marketing is that consumers in different countries have varying conventions and customs, so they simply do not use products the same way. So it means that we all have different perceptions of the world and that we will not react the same way to the same things mentioned.

Some large corporations, such as Coca Cola have been pretty successful at crafting a single, international image still ever the soft drink giant must make minor modifications to the way it presents itself in each culture. Although Coke commercials are largely standardized, the company permits local agencies to edit them so they highlight close ups of local faces (Hill and Winski, 1987)

\section{CULTURAL DIMENSIONS}

According to Hofstede (2011) Culture is the collective programming of the human mind that distinguishes the members of one human group from those of another. Culture in this sense is a system of collectively held values.

Hofstede (2011) identifies cultural dimensions that are globally applicable and are reflected in all aspects of life, including family life, child-rearing practices, education, employment, and health care practices. These cultural dimensions include:
(1) Individualism - collectivism

The individualism-collectivism dimension relates to a societal, not an individual's, characteristic and identifies the extent to which people in a society are integrated into groups. In an individualist society, there is an expectation that individuals look after themselves and connections between individuals are loose; while in a collectivist society, individuals are integrated into strong, cohesive groups, which may often involve extended family. Vertical individualism is a cultural orientation in which an autonomous self is also valued, but the self is seen as different from and perhaps unequal to other. Status and competition are important aspect of this orientation. Horizontal collectivism is a cultural orientation in which the individual sees the self as part of an in group whose members are similar to each other. The self is interdependent and the same as the self of others. Equality is expected and practiced within this orientation.

(2) High Context and Low Context

High context cultures would generally be associated with collectivism, whereas, in contrast, low context cultures would typically be correlated with individualism. In collectivistic countries, messages flow more easily because of the interpersonal relationships within a group, while there is more need for explicit and direct communication in individualistic societies.

(3) Power distance

Power distance refers to the extent to which less powerful members of organizations and institutions (including the family) accept and expect unequal power distributions. This dimension is measured not only from the perspective of the leaders, who hold power, but from the followers. In regard to power distribution, Hofstede notes, "all societies are unequal, but some are more unequal than others."

(4) Masculinity - femininity Masculinity-femininity cultural dimension is addressed as a societal, not an individual's, characteristic and refers to the distribution of values between the genders. A society is called feminine when there is not a strong 
differentiation between the genders for emotional and social roles-both men and women should be modest and caring and both boys and girls may cry, but neither should fight. In masculine societies, both men and women are assertive and competitive; however women are less so than men.

(5) The uncertainty avoidance

The uncertainty avoidance dimension indicates the level of comfort with unstructured situations, in which unstructured situations are novel, unknown, surprising, and different from usual. The uncertainty avoidance encompasses a culture's tolerance for ambiguity. Cultures high in uncertainty avoidance avoid unstructured situations with "strict behavior codes, laws and rules, disapproval of deviant opinions, and a belief in an absolute truth.

(6) Long- and Short-Term Orientation

The long- versus short-term orientation refers to whether a society exhibits a pragmatic future-oriented perspective or a conventional historic point of view. A long-term orientation fosters virtues directed toward the future, in particular, perseverance and thrift and ordering relationships by status. A short-term orientation fosters virtues related to the past and present, in particular, respect for tradition, preservation of "face," and personal steadiness and stability

(7) Indulgence Versus Restraint

This dimension identifies the extent to which a society allows "relatively free gratification of basic and natural human desires related to enjoying life and having fun as represented by the indulgence point on the continuum, relative to a society that controls gratification of needs and regulates by means of strict social norms. Indulgence as a cultural value also tends towards a perception of personal life control, while restraint as a cultural value tends towards a perception of helplessness and that what happens in one's life is beyond his/ her own control.

\section{HIGH CULTURE AND MASS CULTURE}

The differentiation between levels of culture is generally seen as an elitist perception of culture. High culture is considered to encompass a set of products, especially in the arts, of a higher status, held in the highest esteem. On this cultural level "the emphasis is on the work's cultic value" (Benjamin, 2008:. 12). The term high culture is used to describe a subculture shared by the elite in a society. Products of high culture are mostly viewed as belonging to the long-established forms of art, such as painting and sculpting. Examples of these products include paintings by Michelangelo and symphonies by Mozart.

On the other hand, there is what is commonly referred to as Low culture or in a less derogatory term, Popular culture. On this level the emphasis is instead on the work's "display value" (Benjamin, 2008 : 12). It is considered the lowest form of art, often completely lacking in creativity. The most obvious examples of popular culture include pop music and reality television shows. This level of culture can also be associated with mass culture or the "Culture Industry" (Adorno, 2001: 98) as it is created not by the masses but for the masses.

Lang and Lang (2009) stated that mass culture has come into wide use as a term deprecating the value of commercially marketed arts and entertainment packaged to appeal to people in particular demographic categories. While (Pease, 2000 : 72) considered mass culture as mass produced form of cultural entertainment such as fiction, radio and films were destructive to the quality of individual lives and hence the fabric of society as a whole.

The concepts of high and low can be seen from a strictly elitist perspective High culture containing the most 'intelligent', meaningful and usually long-established works of art, and Low culture encompassing all aspects of mass media and popular culture, grouped under 'Culture Industry' label This pictures the audience of Low culture as naive victims of capitalism, with no conscious autonomy. High and Low culture can be regarded as unclear and subjective cultural statuses that vary and merge over the course of history. Technological reproduction is seen as a positive evolution in bringing the two cultural levels together (Flybring, 2012).

Art and meaningful symbols often used in advertising to attempt to influence people in order to buy the products or services. A lot of high art has been created for aesthetic reasons alone, while some low art has been produced with cultic 
or spiritual ideas in mind. Advertising applies art besides science. It can be seen from the execution of advertising strategy through music, film or design (including color and illustrations). A work of art may use elements from both high and low culture, but its status cannot be confirmed until it receives a social response. Since advertisements distribute by mass media to reach target audience so that its grouped under culture industry for classified as mass culture.

\section{CROSS CULTURAL ADVERTISING}

Cross-cultural advertising means that marketing products or services to several diverse cultures simultaneously (Parry, 2010). It similar to the term of international advertising as pointed by Mooij (2010:385) as advertising, created at, coordinated or directed from one central point, for execution, with or without local adaptations, in a number of countries. The most common usage of the term international advertising is in the context of advertising for brands being marketed in several countries. Such advertising is also referred to as global, multinational, multi country, or crossnational advertising.

A review of cross-cultural advertising research by Okazaki, Mueller and Taylor (2010) shows that most cross-cultural advertising research topics were cultural values and the most used research methods were content analysis and survey. Content analysis has been criticized for providing description without prescription (Samiee \& Jeong 1994). However, the use of content analysis is for measuring the degree of standardization of advertising. Observation of actual practice by content analysis demonstrates what companies do in reality and may as well uncover important advertising appeals and styles for other cultures than the home culture.

Koga and Pearson (1992) found that Japanese advertisers use more social strategies which correlate with collectivistic, vertical and high context culture, while the American advertisers use more individual strategies which correlate with individualistic, horizontal and low context culture( Other research was done by Lin, Koroglu and Olson (2012) showed that the United States commercials used hard sell appeals, displayed individualistic values, and exhibited low context culture values, whereas Chinese commercials relied more on soft sell appeals, displayed collectivistic values, and exhibited high context culture values.

One of the main issues in international marketing and advertising is whether consumers from different countries will become more and more alike or whether the differences will remain stable or even will grow more. The question is reflected at a decisional level by the dilemma of the standardization (globalization) of marketing and advertising strategies or, at contrary, of their cultural adaptation to the paradigms and patterns revealed by every single country/region. The last two decades saw a proliferation of cross cultural studies, research and analysis of advertising, consumer behavior, organizational behavior which attempting to support one approach or the other (Sauciuc, 2002).

Global campaigns would be successful only in a context of cultural and behavioral convergence between the countries where they are delivered; opposite conditions would lead to failure. Dahl (2004) conducted a research about the cross-cultural advertising in order to determine what we know about the links between culture and advertisements. He concluded that the standardization of advertising across culture is not valid today.

According to Sotomayor (2005), all product $\mathrm{s}$ in the world can be divided in two categories: tradition-free (global) products and culture bond (local) products.

\section{(1) Tradition - free products}

Tradition free products can be identified with technological, scientific or financial products, whose main selling points are based on performance. They require much less cross -cultural adaptation, since their perception and values are based on facts, performance and achievement; they are measurable and not very emotional. Communication from technological, financial or scientific companies is usually quite easily adapted from one culture to another, at least when it comes to core values. There might be local variations in the perceived purpose of technology within the local context, but no fundamental resistance. This means that the global strategy can be very consistent, and that much of the creative work and content can 
be shared across the media and across nations (2) Culture-bound products

Culture-bound products are those deeply rooted in national, local or sub - cultural traditions. For example, food, entertainment, lifestyle, some sports, and travel. They take longer to adapt, and in order to enter the global era they often have to change their image substantially and create a new set of values suited for the international market which often coexist alongside the home market ones. They require a much more glocal (global but local) approach. So the positioning of the same brand can vary enormously between countries. The first obvious difference in perception is the local vs. foreign. Being qualified as foreign can be fine if the perception is positive.

Past studies have shown that advertisement of one culture do not necessary work in other cultures (Hung \& Belk : 2007, Jones, 2000). Kansal (2012) noticed that some content of advertisements can be standardized giving a universal appeal to communication strategy. The appeals used in advertising related only across few dimension of culture. Nevertheless, cultural-values play a significant role in advertising strategies. An advertisers must, therefore, tailor its strategy to the sensibilities of each specific culture

Advertising reflects and influences our cultural value and, therefore, it cannot be ignored when building effective advertising. Cultural value is an important element that widely influences behavior. Cultural value dictates the behavior of human beings, and is a continuous force that drives motivation. Value is also considered to be a main part of someone's personality; nonetheless it is learnt through experiences which are subsequently shared personally and socially. In this view, this was proven to be a concept which connects culture, social structure and personality, and plays a role as the standard for choice, belief, attitude and the behavior of mankind. (Mooij, 1997)

Cross cultural awareness aims to help minimize the negative impact of cross cultural differences through building common frameworks for people from different cultures to interact within.

There are some areas of cross-cultural differences in advertising that should be considered in order to successfully incorporate characteristics to complement the values, traditions, and perceptions of the target market, whether locally or abroad. Those are applied in areas such as language, communication style, images and cultural values (Payne, 2004).

\section{Language}

It may seem somewhat obvious to state that language is the key to effective cross cultural advertising. However, the fact that companies persistently fail to check linguistic implications of company or product names and slogans demonstrates that such issues are not being properly addressed. It is imperative therefore that language be examined carefully in any cross cultural advertising campaign.

\section{Communication Style}

Understanding the way in which other cultures communicate allows the advertising campaign to speak to the potential customer in a way they understand and appreciate. Generally communication should be straight forward and to the point. But when attempting to relate to different cultural markets each respond to a different style and understanding the style that is appropriate is vital in creating an effective marketing campaign for any business. Know whether each culture prefers direct or indirect communication, aggressive or passive calls to action, emotional or rational appeals, and a fast or slow pace of speech can help to establish connections with consumers, since we will be speaking to them in familiar ways.

\section{Image}

Images are also culturally sensitive. Whereas it is common to see pictures of women in bikinis on advertising posters on the streets of London, such images would cause outrage in the Middle East. The bottom line is that to create ads that appeal to different cultures, remember to be aware of the principles and traditions observed in each culture. The best way to accomplish this is identify your target market's needs, wants and desires. Analyzing all of the images in an ad for cultural acceptance and understanding that different colors and settings evoke different emotions in different cultures. 


\section{Cultural Values}

When advertising abroad, the cultural values underpinning the society must be analyzed carefully. Is there a religion that is practiced by the majority of the people? Is the society collectivist or individualist? Is it family oriented? Is it hierarchical? Is there a dominant political or economic ideology? All of these will impact an advertising campaign if left unexamined. For example, advertising that focuses on individual success, independence and stressing the word "I" would be received negatively in countries where teamwork is considered a positive quality. Rebelliousness or lack of respect for authority should always be avoided in family oriented or hierarchical societies.

By way of conclusion, we can see that the principles of advertising run through to cross cultural advertising too. That is : know your market, what is attractive to them and what their aspirations are. Cross cultural advertising is simply about using common sense and analyzing how the different elements of an advertising campaign are impacted by culture and modifying them to best speak to the target audience.

\section{Facing Challenges}

One of the biggest problem areas in advertising communication lies with the independent, self directed consumers at whom the message is aimed. The problem is that advertisers have no control over consumer's attention. The problem with the viewer (listener, reader) audience is that you seldom know what is going on in their minds. You don't know if they are attending to your message, if they understand it or if they care about it. They may hear different meanings in your words and see different things in your pictures. They may misinterpret everything you say and may not believe you (Moriarty, 1997: 78)

Advertising is purposeful communication which intends to accomplish something, to have some specific effect on its intended audience. It can also be said that advertising is about communicating meaning but how do we know what that something means? Very often we make sense of a word, phrase, or image because we've learned to associate extremely subtle cultural distinctions with it. Semiotic is the field of study that looks at the relationship between signs, symbols and their role in assignment of meaning. Advertisers turn to semiotics to help understand what meanings people assign to specific symbols. These may vary across taste cultures and geographies.

Most of the problems caused by crosscultural clashes are usually the result of the failure by some or all parties involved to recognize and account for differences in culturally-based communication styles. They assume that all people communicate using the same set of modes and rules (many of which, like body language styles, are unconsciously held).

Advertising has evolved over the years with more sensitivity to culture, and more awareness to cultural diversity. How communication works and how advertising works is culture-bound. In one culture, advertising is persuasive by nature; in another, it is meant to build trust between companies and consumers. Thus, models of one culture cannot be projected to other cultures. The basic difference is between communication styles. Different verbal and nonverbal communication styles can be recognized in both interpersonal and mass communication, and culture clusters can be defined where one or other style prevails. This is related to the way people process information. For some, pictures contain more information than words; for others, the only way to convey meaning is verbal. People look at how advertising works from the perspective of their own culture, which may indeed be very different from the perspective of their counterparts in other.

The other challenges for cross cultural advertising include making decisions to standardize or adapt advertising based on the different points of view of the target audience or customer. Those who favor standardization are mainly concerned with cost reduction of advertising and a consistent brand image worldwide while proponents of adaptation point differential advantage through local adaptation. The aim of adapting the advertisement is to gain maximum effectiveness in terms of response and sales. It allows responsiveness and adaptation to culture, infrastructure and competition. The visual and verbal parts of advertising are mostly sensitive to adaptation and use of local language, models and scenery 
increases the probability for the advertisement to be effective. Therefore, adaptation of creative presentations and decentralized implementations of campaigns are expected to offer greater benefits than less culturally-tied functions. (Mooij, 2010 :159)

In an educational setting, department and school of communication that teach advertising face the challenge of preparing students to design advertisements and related materials that communicate effectively to diverse cultures. To do so, students need to obtain a knowledge and understanding of diverse cultures to help students see clearly how culture affects advertising appeals.

\section{CONCLUSION}

With the increasing growth of the world economy caused by globalization advertising has reached people from different cultural environments. Although advertisements may rapidly transit the globe, the response of those viewing and listening within a variety of cultural contexts and practices are not uniform. Global media does not create uniform habits and attitudes for advertising, marketing and business.

Advertising can be seen as mass culture based on the characteristics of message content, production and distribution. The advertisements message content can be both low and high culture. The copywriter and creative designer have to consider cultural dimensions that fit the culture of the target audience as well as pay attention to product categories which are tradition-free (global) products and culture bound (local) products.

Challenges in cross cultural advertising are: (1). Communicating effectively to audiences from diverse cultures, (2) Deciding between standardization advertising and adaptation advertising to local culture of the audiences, and (3). Preparing advertising students to create advertisements for diverse cultures.

By developing one approach for multiple markets, an advertiser benefits from economies of scale because it does not have to spend substantial time and expense to develop a separate campaign for each culture. In fact, each culture is unique with its own value system, conventions and regulations. An advertiser must, therefore tailor its strategy to the sensibilities of each specific culture. The cultural values content in advertisements had been adapted to local cultures of the target audience. The challenges in delivering messages which contain cultural values have been handled by using language, communication style and image in accordance with the cultural environment of the target audience.

\section{REFERENCES}

Adorno, Theodor W. (2001). The Culture Industry: Selected Essays on Mass

Culture. London: Routledge Classics.

Benjamin, Walter (2008). The Work of Art in the Age of Mechanical Reproduction, 'Great Ideas' (trans. J. A. Underwood). London: Penguin Books

Brinkley, Alan. (1991). American History : A Survey. Mc. Graw Hill. New York.

Dahl, Stephan. (2004). Cross Cultural Advertising Research: What Do We Know about The Influence of Culture On Advertising. London : Middlesex University Business School

Eriksen, Thomas Hylland. (2007). Globalization : The Key Concepts . Oxford: Berg

Flybring, Johan. (2012). Is it Still Possible to Distinguish Between High and Low Culture? Retrieved from https://johanflybringessays. files.wordpress.com

Hemer, Oscar and Thomas Tufte. (2005). Media and Glocal Change. Rethinking Communication for Development. Buenos Aires, Göteborg: CLACSO/Nordicom.

Hofstede, G. (2011). Dimensionalizing cultures: The Hofstede Model In Context.

Online Readings in Psychology and Culture. Retrieved from dx.doi.org/10.9707/2307-0919.1014.

Hopper, Paul. (2007). Understanding Cultural Globalization. Cambridge: Polity Press.

Hung, KH, Li, SY \&Belk, RW. (2007). "Global Understanding : Female Readers Perceptions Of The New Woman In Chinese Advertising" Journal of International Business Studies. Vol 38 No 6. p 1034-1051

Jones, JP. (2000). International Advertising: Realities and Myths .Thousand Oak, California : Sage Publications.

JS, Hill \& JM, Winski. (1987). Good bye Global Ads : Global Village is Fantasy Land for Big Marketer. Advertising Age Vol 58, No 49, p. 22-36

Kansal, Purva. (2012). Advertising Appeals of Globalization Companies: Cross Cultural Lesson From India and US OTC Drugs 
Industry. Conference Conducted at UNA Campus, Himachal Pradesh, India.

Koga, Yago \& Pearson, Bethyl A. (1992). “ Cross Cultural Advertising Strategies in Japanese Vs American Women's Magazines," Journal of Intercultural Communication Studies Vol 2, No 1, p. 23-40

Lang, Kurt \& Lang, Gladys Engel. (2009). “Mass Society, Mass Culture, and Mass Communication: The Meaning of Mass, " International Journal of Communication 3. p.998-1024.

Lin, Ye, Koroglu, Didem \& Olson, Lyle. (2012). The influence of Cultural Values in Advertising . Examples From China and The United States. Conference Conducted at Istanbul, Turkey.

Mooij, MD. (1997). Advertising Worldwide-Concepts, Theories and Practice of

International and Global Advertising. Prentice Hall Publications.

Paradoxes. Sage Publications. Inc

Malefyt \& Moeran. (2003). Advertising Culture. UK : Berg.

Moriarty, SE. (1997). Advertising Creative Strategy : Theory and Practice. New York : Prentice Hall Publications

Neuliep, JW. (2003). Intercultural Communication : A contextual Approach. $2^{\text {nd }} . e$. Boston : Houghton Mifflin Company.

Okazaki, Shintaro. Mueller, Barbara. Taylor, Charles R. (2010). Global Consumer Culture Positioning: Testing Perceptions of Soft-Sell and HardSell Advertising Appeals Between U.S. and
Japanese Consumers. Journal of International Marketing. Vol. 18, No.2, p. 20-34

Parry, Linda.(2010) . Cross Cultural Advertising. Retrieved on 14 November 2014 from www. chrone.comhttp://www.chrone.com/

Payne, Neil. (2004) . Advertising in Contemporary Society. Retrieved on 14 November 2014 from www.buzzle.com/editorial/11-13-2004-61590. asp

Pease, Allison. (2000). Modernism, Mass Culture and The Aesthetics of Obscenity. Cambridge : Cambridge University Pers

Roberston, Roland. (2009). Gobalization : Social Theory and Global Culture. London : Sage Sauciuc, Gabriela. (2002). Cultural Values in Danish Advertising. Retrieved from www.limbistraine. com/ro/cercetare/Gabriela-Sauciuc/1. Introduction-to-cross cultural-advertisingresearch html

Sotomayor, Jesus Maroto Ortiz. (2000). Cross Cultural Digital Marketing in the Age of Globalization .Unpublished Ph.D Thesis. Universitat Rovira I Virgil, Tarragona, Spain. Retrieved from www.jesusmaroto.com/images/Maroto_ MinorDissertation pdf

Steger, Manfred. (2009). Globalization: A Very Short Introduction. USA: Oxford University Press.

Wei, R , \& Jiang J. (2005). Exploring Culture's Influence on Standardization Dynamics of Creative Strategy and Execution in International Advertising. Journalism and Mass Communication Quarterly, 82 (4), p. 838-856 